\title{
Снижение степени окислительного коричневения эксплантов при in vitro культивировании хлопчатника
}

\author{
() Э.А. Баймухаметова ${ }^{1 *}$, Д.Ю. Швец ${ }^{2}$, Х.Г. Мусин ${ }^{1}$, Б.Р. Кулуев ${ }^{1,2}$ \\ ${ }^{1}$ Институт биохимии и генетики УФИЦ РАН \\ Россия, Республика Башкортостан, 450054 г. Уфра, Проспект Октября, 71, лит. 1 Е. \\ ${ }^{2}$ Башкирский государственный университет \\ Россия, Республика Башкортостан, 450076 г. Уфа, улица Заки Валиди, 32.
}

*Email: elvina.baimuhametova@yandex.ru

Исследовалось воздействие различных химических соединений на степень окислительного коричневения эксплантов и каллусов хлопчатника при in vitro культивировании. Наиболее эффективным ингибитором коричневения эксплантов оказался активированный уголь (200 мг/л).

Ключевые слова: хлопчатник, фенольные соединения, окислительное коричневение, агробактериальная трансформация.

Одной из частых проблем, возникающих при in vitro культивировании многих видов растений, в том числе и хлопчатника Gossypium hirsutum L., является потемнение (коричневение) растительных тканей [2]. Причиной этого является активный синтез веществ фенольной природы с их последующим окислением, в результате чего, в клетках появляются окрашенные полимерные фенольные соединения, негативно влияющие на эффрективность генетической трансформации и регенерации растений $[3,7]$. Однако, несмотря на высокую распространенность окислительного коричневения, на сегодняшний день нет универсального способа борьбы с ним. Чаще всего используется метод модификации питательных сред различными химическими веществами, способными препятствовать окислению фенольных соединений - антиоксиданты, либо связывать их, препятствуя их дальнейшему окислению - адсорбенты [6].

Целью данной работы являлось исследование влияния ряда химических соединений, наиболее широко применяющихся для решения данной проблемы, на степень окислительного коричневения эксплантов хлопчатника при in vitro культивировании. Для этого семядольные экспланты хлопчатника сорта Юлдуз, характеризующегося повышенным коричневением, помещались в чашки Петри с питательной средой Мурасиге-Скуга, дополненной: активированным углем (200 мг/л), аскорбиновой кислотой (10 мг/л), тиосульфратом натрия (250 мг/л), нитратом серебра (7 мг/л), поливинилпирролидом (10 мг/л). Экспланты в течение месяца культивировались на данных средах, после чего проводилась визуальная оценка степени коричневения питательной среды и эксплантOB.

Известно, что тиосульфат натрия, аскорбиновая кислота и нитрат серебра при добавлении в питательные среды оказывают антиоксидантное действие, препятствуя окислению выделяющихся в питательную среду фенольных соединений $[1,4,5]$. Однако в данном эксперименте они показали различную эффрективность в выбранных концентрациях. Так, аскорбиновая кислота, широко применяющая для сокращения коричневения тканей ряда растений при in vitro культивировании, в выбранной концентрации 
не оказала значимого эффректа на коричневение тканей хлопчатника. Экспланты, содержащиеся на среде с аскорбиновой кислотой, а также образующиеся на них каллусы, темнели и постепенно погибали (рис.1Б).

Снижению степени коричневения эксплантов способствовал нитрат серебра, однако большинство образующихся на эксплантах каллусов были гидратированными (рис. 1А).

Лишь добавление в питательную среду тиосульфата натрия в концентрации 250 мг/л способствовало сокращению коричневения эксплантов хлопчатника без влияния на характер образующихся каллусов (рис. 1В).

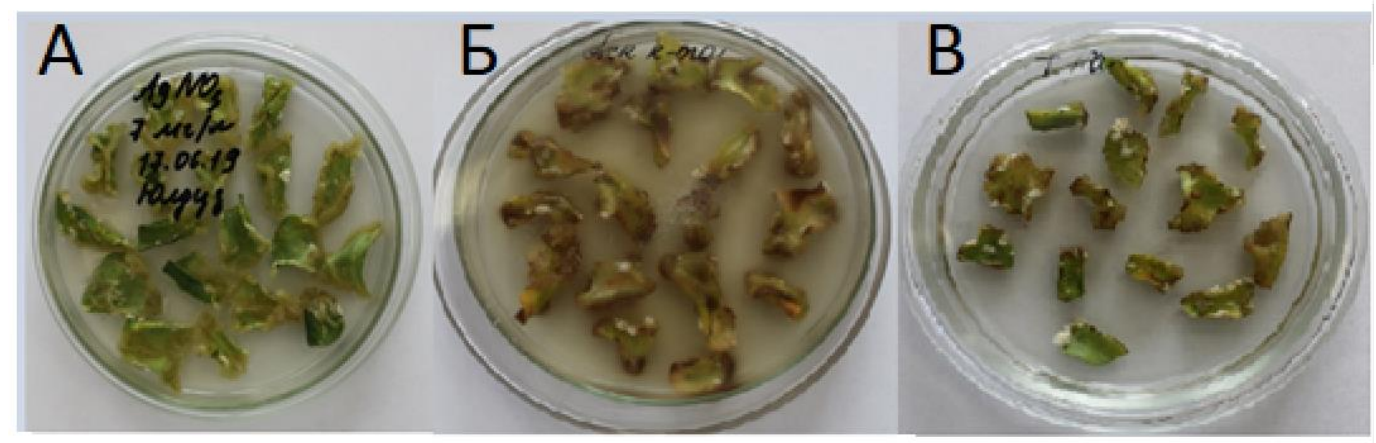

Рис.1. Экспланты хлопчатника, растущие на среде, содержащей: А - нитрат серебра (7 мг/л), Б - аскорбиновую кислоту (10 мг/л), В - тиосульфрат натрия (250 мг/л).

Помимо антиокислителей для борьбы с коричневением можно использовать адсорбенты, такие как ПВП и активированный уголь [8]. ПВП - высокомолекулярный водорастворимый полимер, способный связывать фенольные соединения, образовывая с ними водородные связи и, тем самым, препятствуя их дальнейшему окислению. Чаще всего при культивировании растительных тканей используют ПВП с молекулярной массой 40000. Однако добавление ПВП в концентрации 10 мг/л в среду для культивирования хлопчатника не препятствовала, а даже способствовало коричневению эксплантов хлопчатника. Более того, использование ПВП приводило к снижению эффрективности каллусообразования.

Обратный эффеект оказывал активированный уголь - экспланты, растущие на содержащих его средах, оставались зелеными и не темнели, также в эксплантах наблюдалось активное образование каллусов.

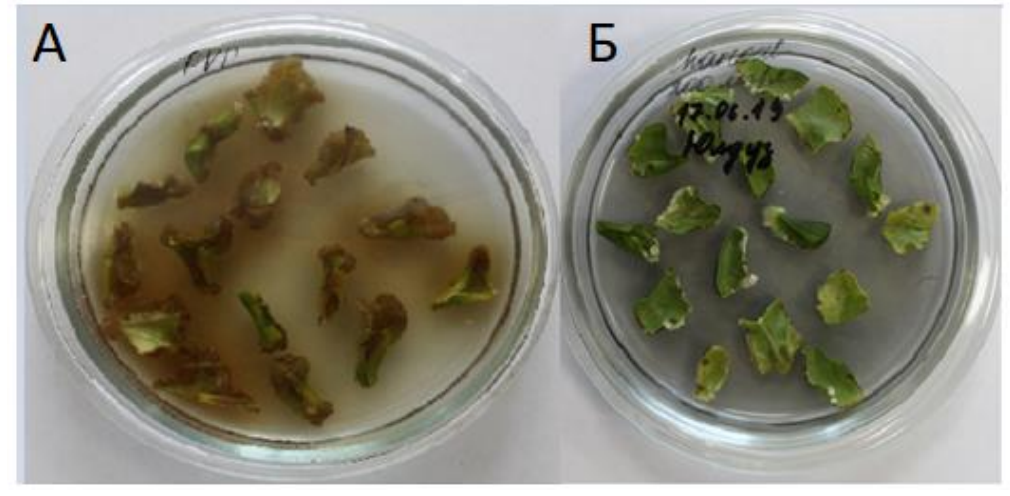

Рис.2. Экспланты хлопчатника сорта Юлдуз, растущие на среде, содержащей: А - поливинилпирролидон, Б - активированный уголь. 
Таким образом, в ходе эксперимента было показано, что для снижения степени коричневения растительных тканей хлопчатника при in vitro культивировании эфффективны активированный уголь и тиосульфат натрия в выбранных концентрациях. Интересно, что аскорбиновая кислота (антиокислитель) и ПВП (адсобент), эффрективно снижающие потемнение тканей ряда других культур, коричневение эксплантов хлопчатника не подавляли. Более того, ПВП в данных экспериментах даже оказывал стимулирующий эффект на коричневение эксплантов.

Можно сделать вывод о том, что целесообразно для каждого вида, сорта растений, а иногда и для типа эксплантов эмпирическим путем подбирать условия культивирования с целью предотвращения окислительного потемнения тканей in vitro. Многие вещества, активно справляющиеся с описанной проблемой при выращивании одной культуры, могут негативно влиять на каллусогенез и регенерацию других культур, что непременно следует учитывать при выборе метода борьбы с окислительным потемнением растительных тканей.

Таким образом, в наших экспериментах наиболее эффективным компонентом для снижения потемнения эксплантов хлопчатника при in vitro культивировании оказался активированный уголь.

Работа выполнена в рамках государственного задания № AAAA-A19-119021190011-0.

\section{Литература}

1. Скапцов М.В., Балабова Д.В., Куцев М.Г. Оптимизация сред для культивирования растений in vitro на примере щавеля водного Rumex aquaticus L. // Сельскохозяйственная биология. 2014. №1. С. 32-35.

2. Ali H.M., El-Gizawy A.M., El-Bassiouny R.E., Saleh M.A. Browning inhibition mechanisms by cysteine, ascorbic acid and citric acid, and identifying PPO-catechol-cysteine reaction products// Journal of food science and technology. 2015. Vol. 52. No. 6. Pp. 3651-3659.

3. Feng J.T., Zhi-yi Z., Jun Z., Na Y., Dmei W. Contamination and browning in tissue culture of Platanus occidentalis L. // Forestry Studies in China. 2007. Vol. 9. No. 4. Pp. 279-282.

4. Kumar G.P., Sivakumar S., Siva1 G., et al. Silver nitrate promotes high-frequency multiple shoot regeneration in cotton (Gossypium hirsutum L.) by inhibiting ethylene production and phenolic secretion // In Vitro Cellular \& Developmental Biology - Plant. 2016. Vol. 52. No. 4. Pp. 408-418.

5. Ndakidemi C.F., Mneney E., Alois P., Ndakidemi A. Effects of ascorbic acid in controlling lethal browning in in vitro culture of Brahylaena huillensis using nodal segments // American Journal of Plant Sciences. 2014. Vol. 5. No. 1. Pp. 187-191.

6. Rana M.M., Han Z.X., Song D.P., et al. Effect of medium supplements on Agrobacterium rhizogenes mediated hairy root induction from the callus tissues of Camellia sinensis var. sinensis // International Journal of Molecular Sciences. 2016. Vol. 17. No. 7. Pp. 1-18.

7. Saengnil K., Lueangprasert K., Uthaibutra J. Control of enzymatic browning of harvested 'hong huay' litchi fruit with hot water and oxalic acid dips // ScienceAsia. 2006. Vol. 32. No. 4. Pp. 345-350.

8. Winkel-Shirley B. Biosynthesis of flavonoids and effects of stress // Current opinion in plant biology. 2002. Vol. 5. No. 3. Pp. 218-223. 
Decrease in the degree of oxidative browning of explants during in vitro cultivation of cotton

\author{
E. A. Baimukhametova ${ }^{1 *}$, D. Yu. Shvets ${ }^{2}$, Kh. G. Musin ${ }^{1}$, B. R. Kuluev ${ }^{1,2}$
}

${ }^{1}$ Institute of Biochemistry and Genetics UFRC RAS

71 Prospekt Oktyabrya, 450054 Ufa, Republic of Bashkortostan, Russia.

${ }^{2}$ Bashkir State University

32 Zaki Validi Street, 450076 Ufa, Republic of Bashkortostan, Russia.

*Email: elvina.baimuhametova@yandex.ru

The effect of various chemical compounds on the degree of oxidative browning of cotton explants and calli during in vitro cultivation was studied. Activated carbon (200 mg / I) proved to be the most effective.

Keywords: cotton, phenolic compounds, oxidative browning, agrobacterial transformation. 